\title{
Production technology for entomopathogenic fungus using a biphasic culture system
}

\author{
Ana Carolina Ribeiro Machado(1), Antonio Carlos Monteiro(1), Aline Maria Belasco de Almeida(1) \\ and Maria Inez Espagnoli Geraldo Martins ${ }^{(2)}$
}

\begin{abstract}
(1)Universidade Estadual Paulista (Unesp), Faculdade de Ciências Agrárias e Veterinárias (FCAV), Departamento de Produção Vegetal, Via de Acesso Prof. Paulo Donato Castellane, s/n, CEP 14884-900 Jaboticabal, SP, Brazil. E-mail: biokarol@hotmail.com, montecar@fcav.unesp.br, amb_almeida@yahoo.com.br (2)Unesp, FCAV, Departamento de Economia Rural,. E-mail: minezesp@fcav.unesp.br
\end{abstract}

\begin{abstract}
The objective of this research was to evaluate combinations of liquid media obtained from agro-industrial residues and by-products, with solid media prepared with mixtures of grains and their derivatives, aiming to increase the production of JAB 02 and JAB 45 isolates of Lecanicillium lecanii. Sporulation, conidial viability and process yield were evaluated as well as the production costs using the JAB 45 isolate as a model system were analyzed. The production of JAB 02 was not increased using the biphasic culture. For JAB 45 , some combinations provided an increase in yield, especially cheese whey with wheat bran and wheat grain, with lower production costs. Viability was not influenced by the production method, and the combinations showed no differences in the process yield. The biphasic method is suitable for the production of L. lecanii, and proves to be an appropriate technology to use in mass production by biofactories.
\end{abstract}

Index terms: Lecanicillium lecanii, conidial viability, liquid media, mass production, solid media.

\section{Tecnologia de produção de fungo entomopatogênico pelo sistema bifásico de cultivo}

Resumo - O objetivo deste trabalho foi avaliar combinações de meios líquidos, obtidos de resíduos e subprodutos agroindustriais, e meios sólidos, preparados com misturas de grãos e seus derivados, visando o aumento da produção dos isolados JAB 02 e JAB 45 de Lecanicillium lecanii. Avaliaram-se a esporulação, a viabilidade de conídios e o rendimento do processo, bem como o custo de produção usando como modelo o isolado JAB 45 foi analisado. A produção de JAB 02 não foi incrementada pelo cultivo bifásico. Para JAB 45, algumas combinações promoveram aumento na produção, especialmente a de soro de queijo com farelo de trigo e trigo em grão, que apresentou o menor custo. A viabilidade não foi influenciada pelo método de produção e as combinações não mostraram diferenças quanto ao rendimento do processo. $\mathrm{O}$ método bifásico é adequado para a produção de L. lecanii, sendo uma tecnologia apropriada para uso com o objetivo de produção massal por biofábricas

Termos para indexação: Lecanicillium lecanii, viabilidade de conídios, meios líquidos, produção massal, meios sólidos.

\section{Introduction}

Microbial control has been considered an important tool in integrated pest management (IPM) and is an ecologically favorable strategy compared to conventional chemical control (Barranco-Florido et al., 2002). In this approach, entomopathogenic fungi are employed as biocontrol agents reducing pest populations and, consequently, their damages in different agro-ecosystems (Inglis et al., 2001).

The use of fungi in the control of agriculturally harmful pests depends on different factors, including the ability to produce high concentrations of stable propagules at a reasonable cost (Jaronski, 1986; Latgé et al., 1986). Industrial production systems for some entomopathogenic fungi use a biphasic method in which the fungal inoculant - mycelia or hyphae - is produced in liquid culture, and then is transferred to solid substrates in order to increase conidial production (Guillon, 1997).

There are several advantages of the biphasic fungal production system. For instance, the liquid culture can act as a barrier against contaminants that might be present in the original culture stock. In addition, this system promotes increased competitiveness of the fungus, thus reducing the risk of the solid substrate

Pesq. agropec. bras., Brasília, v.45, n.10, p.1157-1163, out. 2010 
being colonized by contaminating microorganisms. Additionally, this process ensures a uniform colonization of the solid substrate, resulting in homogeneous fungal growth. Finally, the colonization and production of conidia is faster, reducing the incubation time and economizing physical space (Jenkins et al., 1998).

Although there is a large number of studies on the production of entomopathogenic fungi, the majority focus on the direct production on solid media, while few examine a biphasic culture system.

The fungus Lecanicillium lecanii (Zimmerman) Zare and Gams is one of the most promising agents in the biocontrol of agricultural pests (Lecuona \& Riba, 1991), since it is capable of causing disease in many insects such as aphids, mealybugs, thrips, and white flies, as well as in mites and phytopathogenic fungi (Wenzel et al., 2006). In order to enable the use of this entomopathogen in biological control programs for crop pests, a prior knowledge of the optimal culture conditions (Barbosa et al., 2002) and environmental factors (Monteiro et al., 2004) is necessary, as well as the production of large quantities of fungal conidia. Despite its potential uses, only one reference (Derakhshan et al., 2008) was found for the use of the biphasic culture system to produce this fungus.

The objective of this study was to evaluate combinations of liquid media obtained from agro-industrial residues and by-products with solid media prepared with mixtures of grains and derivatives aiming to increase the production of JAB 02 and JAB 45 isolates of L. lecanii.

\section{Materials and Methods}

Isolates JAB 02 and JAB 45 of L. lecanii [Laboratório de Microbiologia, Departamento de Produção Vegetal, Faculdade de Ciências Agrárias e Veterinárias (FCAV), Universidade Estadual Paulista (Unesp), Jaboticabal, SP] were originally obtained from the green cochineal Coccus viridis (Green, 1889) (Hemiptera: Coccidae) from orange orchards in the municipalities of Ubirajara and São Carlos, São Paulo, Brazil (Barbosa et al., 2002).

The choice of liquid and solid media for the production of $L$. lecanii using the biphasic system was based on the results of Machado et al. (2009). According to these authors, liquid media were prepared with $85 \%$ press water from cassava, $5.5 \%$ sugar cane molasses, $4.0 \%$ Milhocina, and $100 \%$ whey from the production of fresh cheese provided the best results for production of the JAB 02 isolate. For the JAB 45 isolate, liquid media prepared with cassava press water (100\%), Milhocina (4.0\%) and cheese whey (85\%) was the most favorable.

As to the solid media, mixtures composed of course-ground wheat and sorghum at the ratio of $85: 15$, course-ground wheat and lentils (70:30), wheat bran and sorghum (85:15) and wheat bran and lentils (70:30) were the most favorable for the production of the JAB 02 isolate. Media prepared with wheat bran and lentils (70:30), wheat bran and millet (85:15), wheat bran and wheat grain (70:30) and course-ground wheat and lentils (55:45) increased conidial production for the JAB 45 isolate (Machado et al., 2009).

For the biphasic combination between liquid and solid media, the determined concentrations for the preparation of liquid media were made diluting the substrate in distilled water and adding $1 \%$ dextrose to the media composed of $4.0 \%$ Milhocina. The $\mathrm{pH}$ of each medium was adjusted to 6.5 (Monteiro et al., 2004) and $250 \mathrm{mg} \mathrm{L}^{-1}$ chloramphenicol was added to prevent bacterial recontamination after autoclaving. One hundred milliliters of each medium were aliquoted into an Erlenmeyer flask, which was sealed and autoclaved for 20 minutes. After cooling, the media were inoculated with three 8-mm diameter discs taken from fungal colonies grown in BDA medium for 15 days. The fungus was incubated in the dark at $25.0 \pm 0.5^{\circ} \mathrm{C}$ for seven days. After this incubation period, the mycelial mass formed was crushed for five seconds using a vertical mixer and filtered through a 1-mm mesh sieve, resulting in a suspension of mycelial fragments and conidia.

The solid substrate was prepared separately according to the methodology described in Penariol et al. (2008). For treatments with primarily wheat bran substrates, $100 \mathrm{~g}$ of the respective mixtures were placed in polypropylene bags, and for treatments composed of course-ground wheat substrates $200 \mathrm{~g}$ were used. The bags were sealed and autoclaved during 50 minutes. In laminar flow, the media were inoculated with $3 \mathrm{~mL}$ of the liquid medium culture suspension through an approximately $3-\mathrm{cm}$ hole at one end of the polypropylene bags. The open end was sealed and the bags were incubated in the dark at $25.0 \pm 0.5^{\circ} \mathrm{C}$ for 15 days. 
After the incubation period, ten samples totaling $1 \mathrm{~g}$ were randomly collected from each bag with solid media. The material was suspended in $9 \mathrm{~mL}$ of a 1:1 mixture of a saline solution $\left(\mathrm{NaCl} 0.89 \% \mathrm{w} \mathrm{v}^{-1}\right)$ and Tween $80\left(0.1 \% \mathrm{v} \mathrm{v} \mathrm{v}^{-1}\right)$. Then, it was vigorously shaken to release the conidia and filtered through a voile fabric to remove solid particles. The number and viability of the conidia produced from the suspension was determined using a Neubauer chamber, according to the method described by Francisco et al. (2006).

The process yield was determined by collecting $10 \mathrm{~g}$ of substrate with the fungus grown in each bag. This material was suspended in $50 \mathrm{~mL}$ of a Tween 80 -saline solution (1:1), vigorously shaken, stored for 24 hours, and then filtered through a 1-mm mesh sieve. The solid residue retained in the sieve was removed and dried at $60^{\circ} \mathrm{C}$ until it reached constant weight, determined using an analytical scale. The liquid suspension was then centrifuged at $705.6 \mathrm{~g}$ for six minutes and the supernatant discarded. The conidia mass retained in the bottom of the centrifuge tube was also incubated in an oven at $60^{\circ} \mathrm{C}$ until constant weight. The relationship between the dry mass of the conidia and the dry material of the substrate was thereafter determined as percentage.

A production cost analysis was performed using the experimental results. As a model, the production of $50 \mathrm{~kg} \mathrm{day}^{-1}$ of a not formulated product on the basis of the JAB 45 isolate of L. lecanii was simulated, using a small scale biofactory comprising 22 working days per month. The production cost structure applied was the operational costs proposed by Matsunaga et al. (1976) and used by the Instituto de Economia Agrícola, São Paulo, Brazil. The raw material parameter was the only factor altered, as the media that provided the best results were used in the biphasic combination for this isolate. The liquid media were not included in the analysis because they are considered agroindustrial residues and were used in small amounts when compared to the solid media.

The Estat Program (Estat, 1997) was used to carry out the statistical analyses. A completely randomized design was used, and data (four replicates per treatment) were subjected to variance analysis using the $\mathrm{F}$ test. Means were compared using the Tukey test at 5\% probability. The data from the conidial production, viability and process yield were transformed into $\log$ (x), $\operatorname{arcsen} \mathrm{x} / 100$ and $\log \mathrm{x}+1$, respectively.

\section{Results and Discussion}

Conidia production from the JAB 02 isolate was not significantly influenced by biphasic culture among the combinations tested (Table 1). The biphasic combinations using the inoculation produced in the liquid media based on cassava press water, resulted, on average, in higher values for this parameter. Among these, the combination with wheat bran and lentils had conidia production 2.5 times higher $\left(3.58 \times 10^{7} \mathrm{~g}^{-1}\right)$ than the conventional production method $\left(1.42 \times 10^{7} \mathrm{~g}^{-1}\right)$, which uses only solid media (Machado et al., 2009).

The conidia viability from the combination of sugar cane molasses with the solid medium of course-ground wheat and sorghum was significantly lower than with cheese whey and cassava press water (Table 1). The high percentage of viable conidia from the first combination, however, confirms that this fungal production method is fully satisfactory. In relation to process yield, only the combination of molasses with course-ground wheat and lentils differed from the combination of liquid medium with wheat bran and sorghum and Milhocina with course-ground wheat and sorghum, showing that the process yield was very similar concerning all combinations evaluated for the JAB 02 isolate (Table 1).

In some combinations, the biphasic culture system increased conidia production from the JAB 45 isolate, which was of the order of $10^{9} \mathrm{~g}^{-1}$ (Table 2), as the conventional culture on solid media produced $10^{8} \mathrm{~g}^{-1}$ (Machado et al., 2009). The best results were obtained from the combinations of cheese whey with the media containing wheat bran. Among these, the combination of cheese whey with the mixture of wheat bran and wheat grain was the most favorable. This mixture provided a conidia yield 1.9 and 2.4 times greater than that obtained in media containing wheat bran and lentils and wheat bran and millet, respectively, although not statistically different.

The analysis of variance for the viability of the conidia from JAB 45 isolate was not significant (Table 2), indicating that biphasic production and conventional culture on solid media (Machado et al., 2009) did not influence this parameter, which remained higher than $97 \%$ for all the treatments.

Independently of the liquid medium used as the inoculant, the solid medium prepared from course-ground wheat and lentils provided the best yield (Table 2), although this medium favored the 
sporulation of the JAB 45 isolate when combined with Milhocina. The vigorous agitation of the media by shaking and the 24 hours of storage combined with the physical structure of these substrates possibly allowed the release of components that were deposited together with the conidia following centrifugation, and could

Table 1. Conidia production, viability and yield of the biphasic process for the JAB 02 isolate of Lecanicillium lecanii cultured for seven days in liquid medium and 15 days on solid medium, at $25^{\circ} \mathrm{C}$, in the dark ${ }^{(1)}$.

\begin{tabular}{|c|c|c|c|}
\hline Biphasic combinations & $\begin{array}{l}\text { Conidia production } \\
\left(\mathrm{x} 10^{7} \mathrm{~g}^{-1} \text { substrate }\right)\end{array}$ & $\begin{array}{c}\text { Viability } \\
(\%)\end{array}$ & $\begin{array}{c}\text { Process yield }{ }^{(2)} \\
(\%)\end{array}$ \\
\hline Molasses $(5.5 \%) /$ course-ground wheat + sorghum $(85: 15 \%)$ & $0.77 \mathrm{~A}$ & $97.53 \mathrm{~B}$ & $1.42 \mathrm{AB}$ \\
\hline Molasses $(5.5 \%) /$ course-ground wheat + lentils $(70: 30 \%)$ & $0.71 \mathrm{~A}$ & $99.28 \mathrm{AB}$ & $2.99 \mathrm{~A}$ \\
\hline Molasses $(5.5 \%) /$ wheat bran + sorghum $(85: 15 \%)$ & $0.40 \mathrm{~A}$ & $97.58 \mathrm{AB}$ & $0.46 \mathrm{~B}$ \\
\hline Molasses $(5.5 \%) /$ wheat bran + lentils $(70: 30 \%)$ & $1.29 \mathrm{~A}$ & $99.11 \mathrm{AB}$ & $0.89 \mathrm{AB}$ \\
\hline Milhocina $(4.0 \%) /$ course-ground wheat + sorghum $(85: 15 \%)$ & $1.41 \mathrm{~A}$ & $99.25 \mathrm{AB}$ & $0.40 \mathrm{~B}$ \\
\hline Milhocina (4.0\%)/course-ground wheat + lentils $(70: 30 \%)$ & $0.66 \mathrm{~A}$ & $98.66 \mathrm{AB}$ & $1.97 \mathrm{AB}$ \\
\hline Milhocina $(4.0 \%) /$ wheat bran + sorghum $(85: 15 \%)$ & $0.27 \mathrm{~A}$ & $99.33 \mathrm{AB}$ & $1.17 \mathrm{AB}$ \\
\hline Milhocina $(4.0 \%) /$ wheat bran + lentils $(70: 30 \%)$ & $0.31 \mathrm{~A}$ & $99.36 \mathrm{AB}$ & $0.75 \mathrm{AB}$ \\
\hline Cheese whey $(100 \%) /$ course-ground wheat + sorghum $(85: 15 \%)$ & $2.01 \mathrm{~A}$ & $99.61 \mathrm{~A}$ & $1.08 \mathrm{AB}$ \\
\hline Cheese whey $(100 \%) /$ course-ground wheat + lentils $(70: 30 \%)$ & $1.13 \mathrm{~A}$ & 99.39AB & $2.02 \mathrm{AB}$ \\
\hline Cheese whey $(100 \%) /$ wheat bran + sorghum $(85: 15 \%)$ & $0.98 \mathrm{~A}$ & $99.69 \mathrm{AB}$ & $0.52 \mathrm{AB}$ \\
\hline Cheese whey $(100 \%) /$ wheat bran + lentils $(70: 30 \%)$ & $0.25 \mathrm{~A}$ & $99.64 \mathrm{AB}$ & $0.67 \mathrm{AB}$ \\
\hline Cassava press water $(85 \%) /$ course-ground wheat + sorghum $(85: 15 \%)$ & $1.16 \mathrm{~A}$ & $99.78 \mathrm{~A}$ & $0.63 \mathrm{AB}$ \\
\hline Cassava press water $(85 \%) /$ course-ground wheat + lentils $(70: 30 \%)$ & $2.39 \mathrm{~A}$ & $99.58 \mathrm{AB}$ & $1.14 \mathrm{AB}$ \\
\hline Cassava press water $(85 \%) /$ wheat bran + sorghum $(85: 15 \%)$ & $1.26 \mathrm{~A}$ & 99.39AB & $0.72 \mathrm{AB}$ \\
\hline Cassava press water $(85 \%) /$ wheat bran + lentils $(70: 30 \%)$ & $3.58 \mathrm{~A}$ & $99.67 \mathrm{AB}$ & $1.24 \mathrm{AB}$ \\
\hline F test & $1.49^{\mathrm{ns}}$ & $2.59 * *$ & $2.03 *$ \\
\hline$\overline{\mathrm{CV}(\%)}$ & 7.01 & 2.66 & 7.77 \\
\hline
\end{tabular}

(1) Means followed by equal letters, in the columns, do not differ by the Tukey test at $5 \%$ probability. Conidia production, viability and yield were transformed with $\log (\mathrm{x}), \operatorname{arc} \operatorname{sen} \mathrm{x} / 100$ and $\log \mathrm{x}+1$, respectively, for statistical analysis ${ }^{(2)}$ Obtained from the ratio between the dry mass of the substrate and the dry

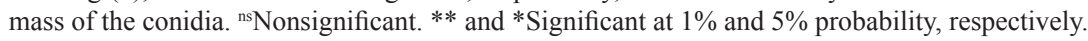

Table 2. Conidia production, viability and yield of the biphasic process for the JAB 45 isolate of Lecanicillium lecanii, cultured for seven days in liquid medium and 15 days on solid medium, at $25^{\circ} \mathrm{C}$, in the dark ${ }^{(1)}$.

\begin{tabular}{lccc}
\hline Biphasic combinations & $\begin{array}{c}\text { Conidia production } \\
\left(\mathrm{x} 10^{8} \mathrm{~g}^{-1} \text { substrate }\right)\end{array}$ & $\begin{array}{c}\text { Viability } \\
(\%)\end{array}$ & $\begin{array}{c}\text { Process yield }{ }^{(2)} \\
(\%)\end{array}$ \\
\hline Cheese whey $(85 \%) /$ wheat bran + lentils $(70: 30 \%)$ & $7.66 \mathrm{AB}$ & $99.36 \mathrm{~A}$ & $1.74 \mathrm{BC}$ \\
Cheese whey $(85 \%) /$ wheat bran + millet $(85: 15 \%)$ & $5.94 \mathrm{AB}$ & $98.06 \mathrm{~A}$ & $2.16 \mathrm{BC}$ \\
Cheese whey $(85 \%) /$ wheat bran + wheat grain $(70: 30 \%)$ & $14.50 \mathrm{~A}$ & $98.61 \mathrm{~A}$ & $1.46 \mathrm{C}$ \\
Cheese whey $(85 \%) /$ course-ground wheat + lentils $(55: 45 \%)$ & $0.26 \mathrm{EF}$ & $98.86 \mathrm{~A}$ & $2.44 \mathrm{ABC}$ \\
Milhocina $(4.0 \%) /$ wheat bran + lentils $(70: 30 \%)$ & $0.17 \mathrm{EF}$ & $98.00 \mathrm{~A}$ & $1.00 \mathrm{C}$ \\
Milhocina $(4.0 \%) /$ wheat bran + millet $(85: 15 \%)$ & $0.02 \mathrm{~F}$ & $99.17 \mathrm{~A}$ & $0.49 \mathrm{C}$ \\
Milhocina (4.0\%)/wheat bran + wheat grain $(70: 30 \%)$ & $0.02 \mathrm{~F}$ & $98.08 \mathrm{~A}$ & $0.47 \mathrm{C}$ \\
Milhocina $(4.0 \%) /$ course-ground wheat + lentils $(55: 45 \%)$ & $3.26 \mathrm{ABC}$ & $98.92 \mathrm{~A}$ & $7.20 \mathrm{~A}$ \\
Cassava press water $(100 \%) /$ wheat bran + lentils $(70: 30 \%)$ & $0.37 \mathrm{CDE}$ & $97.75 \mathrm{~A}$ & $0.57 \mathrm{C}$ \\
Cassava press water $(100 \%) /$ wheat bran + millet $(85: 15 \%)$ & $0.25 \mathrm{DE}$ & $99.31 \mathrm{~A}$ & $0.87 \mathrm{C}$ \\
Cassava press water $(100 \%) /$ wheat bran + wheat grain $(70: 30 \%)$ & $1.56 \mathrm{BCD}$ & $98.78 \mathrm{~A}$ & $0.70 \mathrm{C}$ \\
Cassava press water $(100 \%) /$ course-ground wheat + lentils $(55: 45 \%)$ & $0.07 \mathrm{EF}$ & $98.61 \mathrm{~A}$ & $6.42 \mathrm{AB}$ \\
\hline F test & $28.82^{* *}$ & $0.866^{\mathrm{ns}}$ & $6.78^{* *}$ \\
\hline CV $(\%)$ & 5.13 & 3.42 & 10.26 \\
\hline
\end{tabular}

${ }^{(1)}$ Means followed by equal letters, in the columns, do not differ by the Tukey test at $5 \%$ probability. Conidia production, viability and yield were transformed with $\log (\mathrm{x})$, arc sen $\mathrm{x} / 100$ and $\log \mathrm{x}+1$, respectively, for statistical analysis ${ }^{(2)}$ Obtained from the ratio between the dry mass of the substrate and the dry

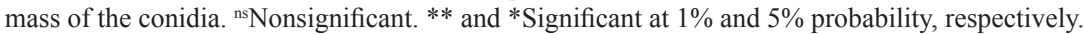


not be removed using the cited methodology. The combinations of cheese whey with mixtures containing wheat bran in addition to favoring sporulation of the isolate did not result in a high yield.

The structure of the substrate may be as important as the available nutrients (Lomer \& Lomer, 2008). According to these authors, an ideal substrate should provide a high ratio between the superficial area and volume where the individual particles remain separated, in order to provide space between particles for aeration and conidia formation. The solid media based on wheat bran and course-ground wheat mixed with either sorghum and lentils or millet and wheat grain were more suitable for the production of $L$. lecanii isolates, possibly responding better to these media due to their textures. Moreover, these substrates are rich in nutrients and the availability of these nutrients in the liquid media contributed to increase the conidia production, especially for the JAB 45 isolate.

An economic analysis (Table 3) considered the media that provided the best results for the production of the JAB 45 isolate. The average operational costs of fungal production in a medium composed of wheat bran and wheat grain at the ratio of 70:30 was the lowest among those analyzed, and provided higher conidia yield per gram of substrate. The estimated sales price is consistent with that of other biological products available in the market. This is important, since the availability of quality products at competitive prices is one of the essential requirements for the effective implementation of biological control with entomopathogenic fungi in Brazilian agriculture.

Different methods were evaluated for the production of L. lecanii, including production using liquid and solid substrates and a combination of them (Derakhshan et al., 2008). These authors observed that the production of conidia using the biphasic culture system with a combination of $4 \%$ sugar cane molasses and grain rice provided an increase of 2.43 and 1.16 times when compared to production in liquid and solid media, respectively. Those results are similar to those found in this research for some of the combinations evaluated for the JAB 45 isolate.

Using the biphasic culture system for the production of Beauveria bassiana (Balsamo) Vuillemin (1912), Santoro et al. (2005) obtained greatest sporulation when rice grain was combined with liquid media made with crysalid flour or with crysalid flour + potato + dextrose, reaching a yield of 2.7 and 2.8 $\mathrm{x} 10^{12} \mathrm{~g}^{-1}$, respectively. According to these authors, the available nutritional source in liquid media influenced sporulation on solid media and, compared to the conventional production of this fungus, there was a 100 to 1,000 fold increase in productivity, which also reduced the production time. Kassa et al. (2008) cultivated B. bassiana and Metharizium anisopliae (Metsch.) Sorokin (1879) in liquid media containing various concentrations of cheese whey, and transferred $10 \mathrm{~mL}$ of these media into Petri dishes to solidify and promote sporulation. Under such

Table 3. Production costs (US\$ per month) ${ }^{(1)}$ for a bioinseticide based on the JAB 45 isolate of Lecanicillium lecanii using the most favorable biphasic combinations.

\begin{tabular}{|c|c|c|c|c|}
\hline \multirow[t]{2}{*}{ Operational cost } & \multicolumn{4}{|c|}{ Solid culture medium $^{(2)}$} \\
\hline & $\mathrm{WB}+\mathrm{Wg}(70: 30 \%)$ & $\mathrm{WB}+\mathrm{L}(70: 30 \%)$ & $\mathrm{WB}+\mathrm{M}(85: 15 \%)$ & $\mathrm{CgW}+\mathrm{L}(55: 45 \%)$ \\
\hline Primary material & 524.40 & $1,024.12$ & 672.46 & $1,567.02$ \\
\hline Contracted hired labor & $2,944.48$ & $2,944.48$ & $2,944.48$ & $2,944.48$ \\
\hline Overhead & $2,173.02$ & $2,173.02$ & $2,173.02$ & $2,173.02$ \\
\hline Taxes and fees & 492.09 & 492.09 & 492.09 & 492.09 \\
\hline Effective operational cost (US\$ per month) & $6,133.99$ & $6,633.71$ & $6,282.06$ & $7,176.62$ \\
\hline Depreciation & 111.58 & 111.58 & 111.58 & 111.58 \\
\hline Production (kg per month) & 1,100 & 1,100 & 1,100 & 1,100 \\
\hline Total operational costs (T.O.C.) (US\$ per month) & $3,502.84$ & $3,783.11$ & $3,585.88$ & $4,087.60$ \\
\hline Average operational costs (US\$ kg-1) & 1.78 & 1.92 & 1.82 & 3.71 \\
\hline Sale price (T.O.C. $+60 \%$ profit margin) & 9.08 & 9.81 & 9.30 & 10.60 \\
\hline Amount of conidia per gram of substrate & $1.45 \times 10^{9}$ & $7.66 \times 10^{8}$ & $5.64 \times 10^{8}$ & $3.26 \times 10^{8}$ \\
\hline
\end{tabular}


conditions, they observed an increase in sporulation for both fungi as a function of the increase in the whey concentration, and the largest productions were obtained with $B$. bassiana, which produced $8 \times 10^{7}$ and $9 \times 10^{7}$ conidia $\mathrm{mL}^{-1}$ in cheese whey concentrations of 62.5 and $87.5 \mathrm{~g} \mathrm{~L}^{-1}$, respectively. Based on these findings, Kassa et al. (2008) considered cheese whey a promising substrate for the production of these fungi, especially because of its environmental aspect, since it is a waste pollutant if not treated by the cheese production industry. Similarly, results obtained for $L$. lecanii in the present study indicates that cheese whey is an adequate medium for fungal production in a biphasic system, since it provided higher conidial production, especially for JAB 45 isolate.

The combination of the liquid media made with soy flour and dextrose and solid media with a broken corn, rice, barley, sorghum, oats and coconut fiber base was evaluated for the production of seven Hirsutella thompsonii Fischer (1950) isolates, and one H. nodulosa Petch (1926) isolate (Rosas-Acevedo et al., 1995). These authors concluded that the biphasic method increased sporulation of both fungi.

The fungi and substrates used in the various studies regarding the biphasic culture system are very diverse, which makes a comparison of the results very difficult. However, an increase in the production of conidia using a biphasic system was noted and verified as a suitable method for promoting fungus production. Thus, results are promising and may stimulate further research aiming to maximize the production of this entomopathogen using a biphasic culture system.

\section{Conclusions}

1. The biphasic culture system increases conidia production of Lecanicillium lecanii in the JAB 45 isolate, and none of the tested combinations increase conidia production in the JAB 02 isolate.

2. The conidial viability of both isolates is not influenced by the production method.

3 . For the JAB 45 isolate, the biphasic combination that provides the best results for conidia production also has the lowest production cost.

\section{Acknowledgements}

To Coordenação de Aperfeiçoamento de Pessoal de Nível Superior, for granting a scholarship to the first author.

\section{References}

BARBOSA, C.C.; MONTEIRO, A.C.; CORREIA, A. do C.B.; PEREIRA, G.T. Crescimento e esporulação de isolados de Verticillium lecanii sob diferentes condições nutricionais. Pesquisa Agropecuária Brasileira, v.37, p.821-829, 2002.

BARRANCO-FLORIDO, J.E.; ALATORRE-ROSAS, R.; GUTIÉRREZ-ROJAS， M.; VINIEGRA-GONZALÉZ， G.; SAUCEDO-CASTANEDA, G. Criteria for the selection of strains of entomopathogenic fungi Verticillium lecanii for solid state cultivation. Enzyme and Microbial Technology, v.30, p.910-915, 2002.

DERAKHSHAN, A.; RABINDRA, R.J.; RAMANUJAM, B.; RAHIMI, M. Evaluation of different media and methods of cultivation on the production and viability of entomopathogenic fungi, Verticillium lecanii (Zimm.) Viegas. Pakistan Journal of Biological Sciences, v.11, p.1506-1509, 2008.

ESTAT: sistema para análises estatísticas. Versão 2.0. Jaboticabal: Faculdade de Ciências Agrárias e Veterinárias, 1997. Disponível em: $<$ http://www.fcav.unesp.br/download2/softwares/estat/>. Acesso em: 10 jan. 2010.

FRANCISCO, E.A.; MOCHI, D.A.; CORREIA, A. do C.B.; MONTEIRO, A.C. Influence of culture media in viability test of conidia of entomopathogenic fungi. Ciência Rural, v.36, p.1309-1312, 2006.

GUILLON, M. Production of biopesticides: scale up and quality assurance. In: BRITISH CROP PRODUCTION COUNCIL SYMPOSIUM, 68., 1997, Farnham. Insecticides: novelty or necessity: proceedings. Farnham: The British Crop Protection Council, 1997. p.151-162.

INGLIS, G.D.; GOETTEL, T.M.; STRASSER, B. Use of hyphomycetous fungi for managing insect pest. In: BUTT, T.M.; JACKSON, C.; MAGAN, N. (Ed.). Fungi as biocontrol agentes. Wallingford: CAB International, 2001. p.23-69.

JARONSKI, S.T. Commercial development of deuteromycetous fungi of arthropods: a criterial appraisal. In: SAMSON, R.A.; VLAK, J.M.; PETERS, R. (Ed.). Fundamental and applied aspects of invertebrate pathology. Wageningen: Society of Invertebrate Pathology, 1986. p.653-656.

JENKINS, N.E.; HEVIEFO, G.; LANGEWALD, J.; CHERRY, A.J.; LOMER, C.J. Development of mass production technology for aerial conidia for use as mycopesticides. Biocontrol News and Information, v.19, p.21-31, 1998.

KASSA, A.; BROWNBRIDGE, M.; PARKER, B.L.; SKINNER, M.; GOULI, V.; GOULI, S.; GUO, M.; LEE, F.; HATA, T. Whey for mass production of Beauveria bassiana and Metarhizium anisopliae. Mycological Research, v.112, p.583-591, 2008.

LATGÉ, J.L.; HALL, R.A.; CABRERA, R.I.; KERWIN, J.C. Liquid fermentation of entomopathogenic fungi. In: SAMSON, R.A.; VLAK, J.M.; PETERS, R. (Ed.). Fundamental and applied aspects of invertebrate pathology. Wageningen: Society of Invertebrate Pathology, 1986. p.603-606.

LECUONA, R.E.; RIBA, G. Primeras etapas del ciclo de desarollo de hongos entomopatógenos. Pergamino: Instituto 
Nacional de Tecnología Agropecuaria, 1991. 30p. (Boletin de divulgación tecnológica, 87).

LOMER, C.H.; LOMER, C.J. Mass production of fungal pathogens for insect control: insect pathology manual. 2008. Avalilable at: $<$ http://www.lubilosa.org $>$. Accessed on: 20 Jan. 2009.

MACHADO, A.C.R.; MONTEIRO, A.C.; MOCHI, D.A.; YOSHIDA, L. Resíduos e subprodutos agroindustriais e grãos como substratos para a produção do fungo entomopatogênico Lecanicillium lecanii. Bragantia, v.68, p.483-491, 2009.

MATSUNAGA, M.; BEMELMANS, P.F.; TOLEDO, P.E.N.; DULLEY, R.D.; OKAWA, H.; PEDROSO, I.A. Metodologia de custo de produção utilizada pelo IEA. Agricultura, v.1, p.123-140, 1976.

MONTEIRO, A.C.; BARBOSA, C.C.; CORREIA, A. do C.B.; PEREIRA, G.T. Crescimento e esporulação de isolados de Verticillium lecanii sob diferentes fatores ambientais. Pesquisa Agropecuária Brasileira, v.39, p.561-565, 2004.
PENARIOL, M.C.; MONTEIRO,A.C.; PITELLI, R.A.; PEREIRA, G.T. Produção de Bipolaris euphorbiae em meios de cultura sólidos e líquidos obtidos de grãos e resíduos agroindustriais. Bragantia, v.67, p.805-814, 2008.

ROSAS-ACEVEDO, J.L.; ALATORRE-ROSAS, R.; SAMPEDRO-ROSAS, L.; VALDEZ-CARRASCO, J. Esporulación de los hongos entomopatógenos Hirsutella thompsonii Fisher y $H$. nodulosa Petch em cultivo mixto. Revista Latinoamericana de Micróbiologia, v.37, p.59-64, 1995.

SANTORO, P.H.; NEVES, P.M. de O.J.; SILVA, R.Z. da; AKIMI, S.; ZORZETTI, J. Produção de esporos de Beauveria bassiana (Bals.) Vuill. num processo bifásico utilizando diferentes meios líquidos. Semina: Ciências Agrárias, v.26, p.313-320, 2005.

WENZEL, I.M.; MONTEIRO, A.C.; PEREIRA, G.T. Produção de conídios de Lecanicillium lecanii em substratos sólidos e líquidos obtidos de grãos. Científica, v.34, p.7-14, 2006.

Received on July 8, 2010 and accepted on September 21, 2010 